\title{
Cascading effects of fishing on Galapagos rocky reef communities: reanalysis using corrected data
}

\author{
Jorge I. Sonnenholzner ${ }^{1}$, Lydia B. Ladah ${ }^{1,3, *}$, Kevin D. Lafferty ${ }^{2}$ \\ ${ }^{1}$ CICESE, Department of Biological Oceanography, Km 107 Carretera Tijuana-Ensenada, Ensenada, Baja California, \\ CP 22860, Mexico \\ ${ }^{2}$ Western Ecological Research Center, US Geological Survey, Marine Science Institute, University of California,
} Santa Barbara, California 93106, USA

${ }^{3}$ Mailing address: CICESE, Department of Biological Oceanography, PO Box 434844, San Diego, California 92143-4844, USA

\begin{abstract}
This article replaces Sonnenholzner et al. (2007; Mar Ecol Prog Ser 343:77-85), which was retracted on September 19, 2007, due to errors in entry of data on sea urchins. We sampled 10 highly fished and 10 (putatively) lightly fished shallow rocky reefs in the southeastern area of the Galapagos Marine Reserve, Ecuador. After the correction, these are the new results: there was a negative association between slate-pencil urchins Eucidaris galapagensis and non-coralline algae. In addition, pencil urchins were less abundant where there were many predators. An indirect positive association between predators and non-coralline algae occurred. Fishing appeared to affect this trophic cascade. The spiny lobster Panulirus penicillatus, the slipper lobster Scyllarides astori, and the Mexican hogfish Bodianus diplotaenia were significantly less abundant at highly fished sites. Urchin density was higher at highly fished sites. Non-coralline algae were nearly absent from highly fished sites, where a continuous carpet of the anemone Aiptasia sp. was recorded, and the algal assemblage was mainly structured by encrusting coralline and articulated calcareous algae.
\end{abstract}

KEY WORDS: Trophic cascade $\cdot$ Fishing $\cdot$ Predation $\cdot$ Population structure $\cdot$ Eucidaris galapagensis Galapagos Marine Reserve · Ecuador

\section{INTRODUCTION}

Fishing has indirect effects on ecosystems, particularly through trophic cascades (Sala et al. 1998a, Pinnegar et al. 2000, Jackson et al. 2001, Bascompte et al. 2005), in which sea urchins are often identified as important grazers. For instance, because sea urchins can structure reef communities (Schiel \& Foster 1986, Hughes et al. 1987, Pearse \& Hines 1987), the fishing of urchin predators can increase the abundance of urchins, which can then overgraze algae (Tegner \& Dayton 1981, Tegner \& Levin 1983, Siversten 2006). Evidence for this effect comes from comparisons of fished areas with marine reserves, which can help restore food webs to their former state (Sala et al. 1998b, Shears \& Babcock 2002, Behrens \& Lafferty 2004, Lafferty 2004, Guidetti 2006).
Fishing has strongly altered the biomass and size distribution of fisheries species in parts of the Galapagos Marine Reserve (GMR) (Ruttenberg 2001, Branch et al. 2002, Bustamante et al. 2002, Okey et al. 2004). Removal of top-predator fish species might explain the high abundance of urchins and other grazers on Galapagos reefs (Bustamante et al. 2007). If this is the case, overfishing could indirectly lead to overgrazing (Edgar et al. 2002). To investigate the direct and indirect effects of fishing in the GMR, we compared communities on fished and protected rocky reefs.

In the GMR, the slate-pencil sea urchin Eucidaris galapagensis (sometimes E. thouarsii) (Doderlein) is the most common species of urchin (Danulat \& Edgar 2002). It is not a fishery species. An omnivore, it often grazes in open shallow reef habitats (Glynn et al. 
1979). Removal of pencil urchins leads to an increase in algal cover (Brandt 2003).

There are 3 conspicuously prevalent predators of urchins: spiny lobsters (Panulirus penicillatus and $P$. gracilis locally called red and green lobster, respectively), slipper lobsters: Scyllarides astori (Martinez 2000, authors' pers. obs.) and Mexican hogfish Bodianus diplotaenia (Labridae) (Wellington 1975, authors' pers. obs.). Lobsters are well-known urchin predators in the Galapagos and elsewhere (including our observations in the field). The hogfish is a wrasse with a large head and mouth, with a robust jaw well suited for its diet of large, heavily shelled invertebrates (Hobson $\&$ Chess 2001).

Okey et al. (2004) concluded that the fishinginduced reduction in the biomass of fishes that eat invertebrates, and of spiny and slipper lobsters could have indirect effects on Galapagos reefs. Lobsters support commercial and artisanal fisheries in the GMR (Danulat \& Edgar 2002, Edgar et al. 2004, Hearn 2006). A recent wave of immigration from mainland Ecuador to the Galapagos is thought to have led to an increase in the extraction of a broad array of species. Spiny lobsters have been an important part of the GMR fishing economy since the 1960s, but yield has declined since the 1980s (Reck 1983, Murillo et al. 2002, Hearn 2004). The slipper lobster Scyllarides astori is currently exploited at a local scale (Hearn 2006), and is caught incidentally in the spiny lobster fishery for personal consumption and sale on the local market (2 to $3 \%$ of the total lobster catch) (Bustamante et al. 2000, Hearn 2004). Recorded catch increased from $2 \mathrm{t}$ (1990s) to $13 \mathrm{t}$ (2003) (Danulat \& Edgar 2002, Molina et al. 2004). Although Bodianus diplotaenia is not a commercial fishery species, incidental catch may occur (Ruttenberg 2001, Murillo et al. 2002, 2003, Molina et al. 2004). Nonetheless, any fishery effects on hogfish are purely hypothetical.

\section{MATERIALS AND METHODS}

Study sites. The GMR lies in the eastern Pacific Ocean, $1000 \mathrm{~km}$ off the coast of Ecuador. It includes 18 major islands and over 100 islets (Snell et al. 1995). We studied 20 shallow rocky reefs in the southeastern biogeographic area (according to Danulat \& Edgar 2002) off Santiago, Santa Cruz, Baltra and Seymour Islands (Fig. 1). The site selection maximized dispersion and minimized variance in bottom topography and depth; 10 sites were open to fishing and 10 sites were within fishing exclusion zones conceived in 1992 and formally established in 2000, when a spatial zonation scheme (propuesta consensuada de zonificación provisional, Resolución 002-200), was agreed on by local stakeholders (Danulat \& Edgar 2002). We selected sites that had experienced a relatively long-term reduction in fishing effort (special tourism sites, sites easily observed by the national park staff, sites where we had personal knowledge of fishing effort, etc.). Nonetheless, due to ongoing uneven compliance with fishing regulations, we designated the no-fishing sites as lightly fished (LF) and the sites open to fishing as heavily fished (HF). We note that even this broad categorization is speculative. However, the extent of fishing that occurs in our LF sites may serve to mask actual fishing effects, and thus our comparisons between LF and HF sites should be regarded as conservative.

A map of seafloor substratum types and habitat features (1:10 000 and 1:25000 scale) was produced from a side-scan sonar survey conducted from 2000 to 2001 (Briones et al. 2002). Each chart was categorized into areas likely and not likely to contain reef habitats for urchin, lobsters, and fish at depths from 0 to $20 \mathrm{~m}$ below mean lower low water. SCUBA divers presurveyed all sites that were safely accessible by boat. Of these, 36 sites had appropriate habitat. We randomly selected 20 sites, stratified by geographic position and fishing category, resulting in $6 \mathrm{LF}$ and $4 \mathrm{HF}$ sites in the NW of our study area, and 4 LF and 6 HF sites in the SE (see Appendix 1 for additional site information; available at: www.int-res.com/articles/suppl/ m375p209_app.xls).

Lobster and fish density estimates. From April 2000 to August 2002, diver pairs surveyed lobsters. Different behavior and microhabitat use by spiny lobster Panulirus penicillatus and slipper lobster led us to sample each species separately. Nighttime surveys (after 19:00 h) comprised 2 transects of 20 min duration at 2 depth strata ( 2 to 5 and 8 to $10 \mathrm{~m}, \mathrm{n}=2$ transects per depth stratum per site). Transects were chosen within the study site based on accessibility and habitat suitable for each lobster species. The total area surveyed per site was calculated using a GPS, and transects of 20 min resulted in an area sampled for spiny lobsters between 11 and $211 \mathrm{~m}^{2}$ ( 3 dives per site) and for slipper lobsters between 39 and $787 \mathrm{~m}^{2}$ (between 3 and 8 dives per site). This resulted in an index of lobster population density, expressed as the mean number of individuals seen per diver per hour for each sampling site (ind. diver $\left.{ }^{-1} \mathrm{~h}^{-1}\right)$ (Hearn 2006): abundance $=N / \Sigma\left(T_{1} \times\right.$ $\left.B_{1}+\ldots T_{\mathrm{n}} \times B_{\mathrm{n}}\right)$, where $N$ is the total number of individuals counted in all dives per site, $T_{1}$ is the duration (time spent, h) of the first dive, $B_{1}$ is the number of divers on the first dive, and $T_{\mathrm{n}}$ and $B_{\mathrm{n}}$ are the duration of and number of divers on the last dive.

Diver pairs surveyed hogfish once per site from May to November 2001 using randomly placed, non-overlapping video transects (VT, $25 \times 4 \mathrm{~m}$, total area surveyed $200 \mathrm{~m}^{2}$ ). Divers with a Hi-8 $\mathrm{mm}$ videocassette 


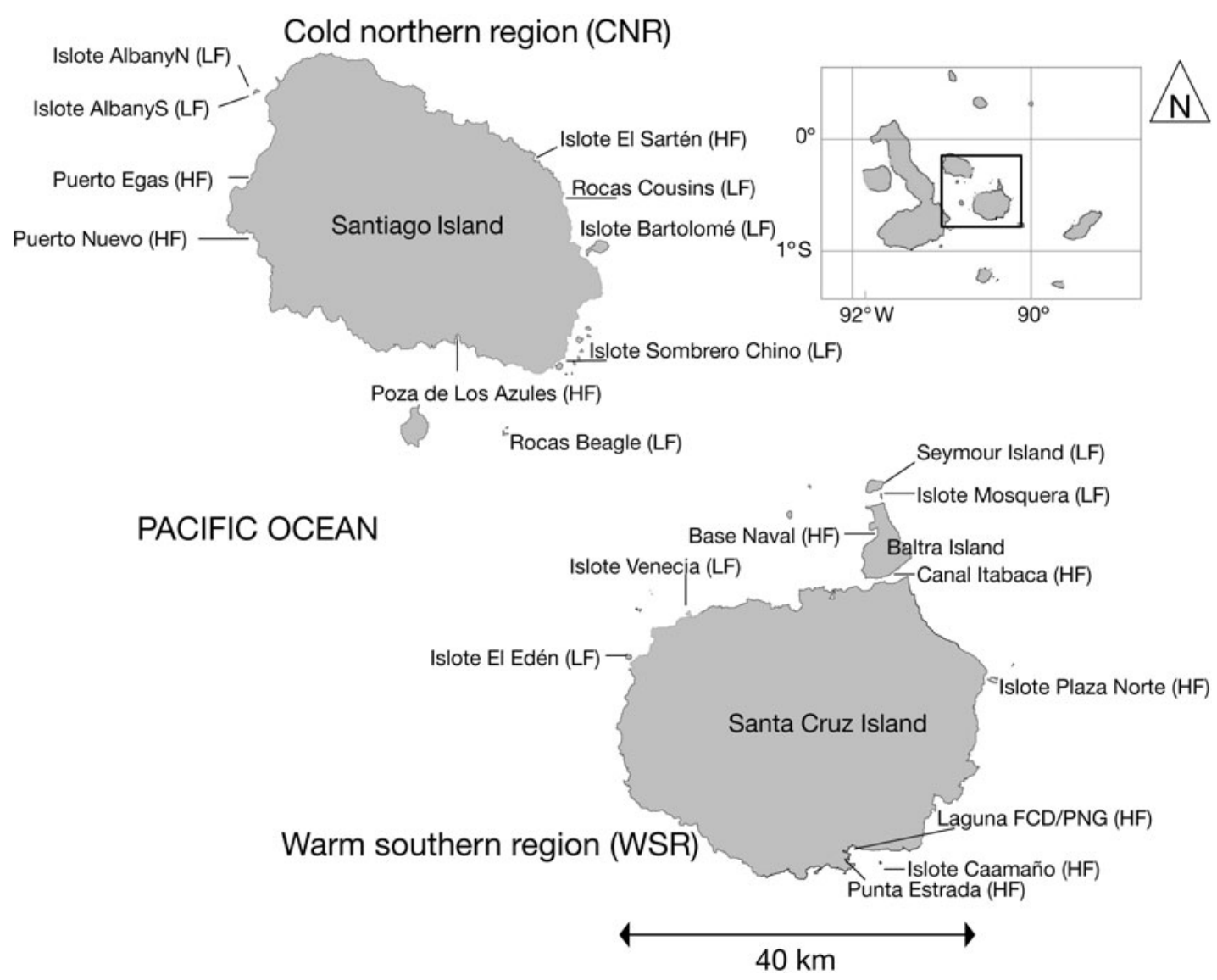

Fig. 1. Southeastern area of the Galapagos Marine Reserve, Ecuador. Data on lobsters, fish, urchins and algae were field collected at 20 sites with different levels of protection from fishing. HF: highly fished sites; LF: lightly fished sites

recorder swam slowly back and forth on either side of the transect line (swath $2 \mathrm{~m}$ wide and $5 \mathrm{~m}$ above the bottom) during a standard 40 min observation period. Transect width was $4 \mathrm{~m}$ and we did not dive if visibility was insufficient to clearly view the entire transect. Subsequent review of the video allowed quantification of adult fish ( $>20 \mathrm{~cm}$ size class).

Predation. Divers collected all whole test remains of the sea urchin Eucidaris galapagensis within the $10 \times$ $2 \mathrm{~m}$ transects. Our index of predation was the number of tests found per live urchin (Sala et al. 1998a). This measure, while convenient, is imperfect; predation events do not always leave remains, and test remains do not indicate a particular predator with any certainty (Sala 1997).

Urchin and algal density. At each site, divers estimated urchin density in 3 replicate $10 \times 2 \mathrm{~m}$ retractable transect lines deployed between 2 and $8 \mathrm{~m}$ depth in October and November 2003. Surveying after 09:00 h optimized underwater visibility. Divers measured - as percentage cover - non-coralline algal abundance (foliose species such as Ulva lactuca, Padina durvillaei, and Dictyota sp. with flattened or membranous blades, but also including more filamentous species, such as Gracil- laria spp.) by using 7 quadrants of $0.5 \times 0.5 \mathrm{~m}\left(0.25 \mathrm{~m}^{2}\right)$ placed during the surveying of urchin transects.

Site covariates. Site factors (besides fishing designation) that we used as covariates were substrate type (sand; and rocks $<1,2$ to 4 and $>4$ m diameter), location (relative distance along a NW to SE axis), current speed (strong, moderate, light, none), protection from wave exposure (highly exposed, moderately exposed, sheltered), land mass (island, islet), slope (flat, moderate incline, steep, wall), and 3 independent measures of temperature, current speed, protection from exposure and slope were subjective measures. Temperatures were measured during each visit. A diver took an average temperature from 12 stations using a Citizen Hyper Aqualand dive computer to the nearest $0.1^{\circ} \mathrm{C}$ at a depth of $10 \mathrm{~m}$. To standardize temperature by season and year, we limited our analysis to a complete set of measures between October and November of 2003. However, because snapshot temperature readings may not reflect the long-term temperature environment, we also obtained sea surface temperature (SST) and CTD readings from the general area of our sites. The SST data were the average of all readings be- 
tween September and November during 2000 to 2003 (Sweet et al. 2007). The World Ocean Database CTD temperatures were from a cruise in November 2005 (Locarnini et al. 2006).

Statistical analyses. In order to consider the wide array of site covariates and maintain degrees of freedom for analysis, we conducted a principal components analysis (PCA) of the 9 site factors listed above. We retained those principal components (PCs) that had an eigenvalue $>1$.

To determine whether communities differed between HF and LF sites, we conducted a MANOVA with algae, sea urchins, lobsters, and hogfish as dependent variables. We also conducted 2 main types of analyses using general linear models: the first assessed associations between trophic levels, and the second compared communities at LF and HF sites. We initially entered all secondorder interactions into a model, but, to preserve degrees of freedom, discarded them if they were non-significant. Similarly, the final model contained only significant main effects (unless a main effect had a significant interaction). We did not include interactions between principal components in our analyses. It should be noted that step-wise regression increases the chance of overfitting the data. For each analysis, we inspected residuals for normality (and the data were transformed if significantly non-normal). We confirmed homogeneity of variances with the Cochran test. Transformation of predator abundances to $Z$-scores weighted all predators equally ( $Z$-scores are standardized to a mean of 0 and an SD of 1). We approximated the potential effects of the predator guild by summing the $Z$-scores of each predator density (we also looked at each predator species separately). We report F-statistics, $\mathrm{R}^{2}$, mean, and $\mathrm{SE}$ (of the least-squared means), unless otherwise indicated. For illustrative purposes, we provide standardized regression coefficients between species to indicate direct negative and indirect positive associations in a food-web diagram. Appendix 1 reports information on sample dates, sample sizes, mean, $\mathrm{SD}$, and other data used in our analyses.

\section{RESULTS}

\section{Site covariates}

The 9 physical variables were decomposed into 4 PCs using PCA (hereafter referred to as PC1 to 4). Together, they explained $79 \%$ of the variation in the 9 physical factors (Table 1). Small rocks and warm temperatures dominated the first eigenvector loadings, strong currents and isolated islets dominated the second eigenvector loadings, steep slopes and shelter from waves dominated the third eigenvector loadings, and shelter and proximity to the northwest dominated the 4 th eigenvector loadings.
Table 1. Eigenvectors for the first 4 principal components (PCs) from 9 physical factors (see 'Materials and methods: Statistical analyses'). SST: sea surface temperature

\begin{tabular}{|lrrrr|}
\cline { 2 - 5 } Variable & \multicolumn{4}{c}{ PC } \\
\cline { 2 - 6 } & 1 & 2 & 3 & \multicolumn{1}{c}{4} \\
\hline Substrate & -0.46 & 0.11 & 0.09 & 0.42 \\
Current speed & -0.09 & 0.55 & -0.13 & 0.39 \\
Location & 0.34 & -0.37 & -0.20 & 0.45 \\
Protection from exposure & 0.15 & 0.34 & -0.48 & -0.46 \\
Land mass & -0.19 & -0.39 & 0.45 & -0.19 \\
Slope & 0.21 & 0.28 & 0.60 & -0.17 \\
Field temperature & 0.46 & 0.15 & 0.14 & -0.16 \\
SST (temperature) & 0.34 & 0.32 & 0.33 & 0.35 \\
CTD (temperature) & 0.48 & -0.28 & -0.11 & 0.20 \\
\hline
\end{tabular}

\section{Evidence for consumer-resource effects}

\section{Direct consumer effects}

During the SCUBA surveys and other field visits we commonly observed evidence of predation on Eucidaris galapagensis. For instance, hogfish and spiny lobster were observed eating pencil urchins on several occasions. Observations of feeding by slipper lobsters were less common, but on the islands of Sombrero Chino and Albany (S), we twice observed slipper lobsters hiding in crevices and eating pencil urchins.

Where urchin predators were abundant, pencil urchins were rare and the index of predation (ratio of tests to live urchins) was high (Fig. 2). The index of predation increased with the summed abundance of predators (Table 2). This association was stronger at sheltered and northwest sites. Urchin density declined strongly with the index of predation (Table 3). Multiple interactions with the physical covariates suggested this association tended to be stronger at sites that were warm, had small rocks, were sheltered, were at large islands, had weak currents, and were in the northwest. A negative association existed between summed predator density and urchin density (Table 4). There was no independent effect of spiny lobsters on urchin density, but slipper lobsters and hogfish densities were significantly negatively associated with urchins (Table 4). Independent of predators, urchin density was higher at sites in the northwest and sites that were sheltered.

Non-coralline (foliose) algae declined with the abundance of urchins (Table 5). This association was strongest at exposed sites and island sites. Algal abundance was associated with other factors besides pencil urchins. More foliose algae occurred at cooler sites, sites with larger rocks, sites with steep slopes, and sheltered sites. 


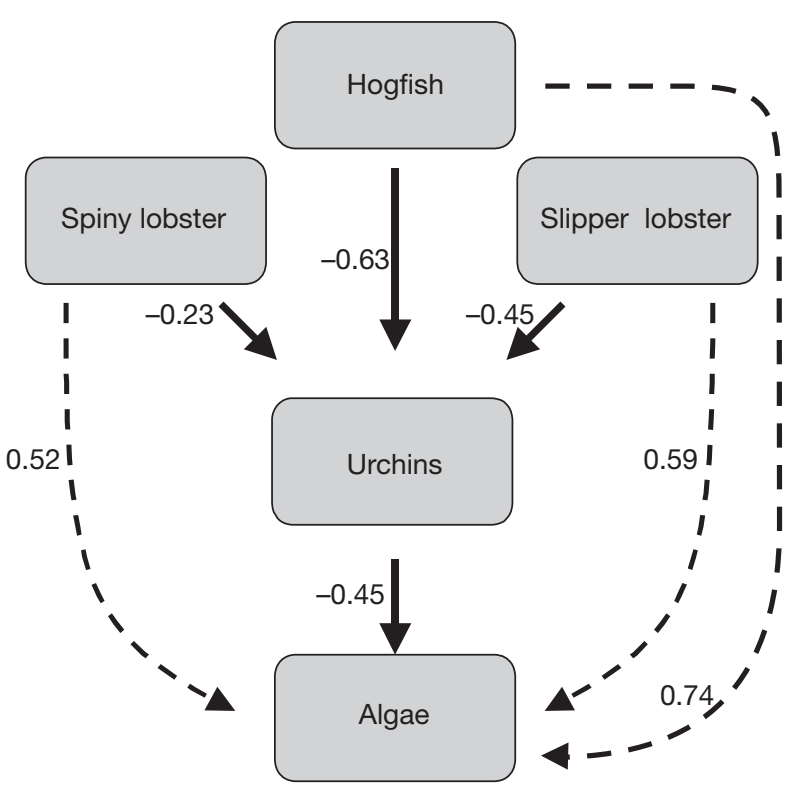

Fig. 2. Simplified Galapagos rocky-reef food web. Solid arrows between boxes represent feeding links. Dashed arrows between boxes suggest indirect effects (trophic cascades). Standardized regression coefficients listed to the left of each line. Hogfish: Bodianus diplotaenia; spiny lobster: Panulirus pencillatus; slipper lobster: Scyllarides astori; urchins: Eucidaris galapagensis

Table 2. Predator density and evidence for predation on urchins. Response is the ratio of urchin tests to live urchins. $\mathrm{R}^{2}=0.59, F_{5,14}=4.0, \mathrm{p}=0.0182$. Pred-Z: Non-significant interactions (PC 2) removed to increase power

\begin{tabular}{|lrcrc|}
\hline Term & Estimate & SE & $t$-ratio & Prob $>|t|$ \\
\hline Intercept & 0.030 & 0.006 & 4.92 & 0.0002 \\
Pred-Z & 0.015 & 0.004 & 3.94 & 0.0015 \\
PC 1 & 0.011 & 0.005 & 2.38 & 0.0321 \\
PC 3 & -0.011 & 0.005 & -1.98 & 0.0681 \\
PC 4 & 0.015 & 0.006 & 2.58 & 0.0217 \\
Pred-Z $\times$ PC 4 & 0.010 & 0.004 & 2.60 & 0.0208 \\
\hline
\end{tabular}

Table 3. Urchin density and evidence for predation on urchins (ratio of urchin tests to live urchins). Response is log urchin density. $\mathrm{R}^{2}=0.80, F_{7,12}=6.9, \mathrm{p}=0.0019$. Non-significant factors (PC 1) removed to increase power

\begin{tabular}{|lrrrr|}
\hline Term & Estimate & SE & $t$-ratio & Prob $>|t|$ \\
\hline Intercept & 0.825 & 0.081 & 10.15 & $<0.0001$ \\
Test:Urchin & -26.188 & 5.967 & -4.39 & 0.0009 \\
PC 2 & 0.198 & 0.071 & 2.79 & 0.0164 \\
PC 3 & -0.103 & 0.050 & -2.07 & 0.0609 \\
PC 4 & 0.207 & 0.104 & 2.00 & 0.0684 \\
$($ Test:Urchin - & 11.194 & 3.689 & 3.03 & 0.0104 \\
0.025) $\times$ PC 2 & & & & \\
$($ Test:Urchin - & -5.889 & 2.183 & -2.70 & 0.0194 \\
$0.025) \times$ PC 3 & & & & \\
$($ Test:Urchin - & 12.818 & 4.605 & 2.78 & 0.0165 \\
$0.025) \times$ PC 4 & & & & \\
\hline
\end{tabular}

Table 4. Urchins and predators. Response is log Urchin density: $\mathrm{R}^{2}=0.34, F_{2,17}=4.5, \mathrm{p}=0.0278$; hogfish density: $\mathrm{R}^{2}=0.43$, $F_{3,16}=3.9, \mathrm{p}=0.0272$; slipper lobster density: $\mathrm{R}^{2}=0.35, F_{2,17}=$ $4.6, p=0.0257$. Non-significant factors (PC 1 to 3 ) removed to increase power

\begin{tabular}{|lrrrr|}
\hline Term & Estimate & SE & $t$-ratio & Prob $>|t|$ \\
\hline log Urchin & & & & \\
Intercept & 0.467 & 0.075 & 6.22 & $<0.0001$ \\
Pred-Z & -0.075 & 0.033 & -2.27 & 0.0364 \\
PC 4 & -0.176 & 0.075 & -2.35 & 0.0312 \\
Hogfish & & & & \\
Intercept & 0.438 & 0.074 & 5.92 & $<0.0001$ \\
Fish-Z & -0.246 & 0.089 & -2.76 & 0.0141 \\
PC 4 & -0.184 & 0.072 & -2.54 & 0.0220 \\
Fish-Z $\times$ Prin4 & -0.149 & 0.078 & -1.91 & 0.0747 \\
Slipper lobster & & & & \\
Intercept & 0.467 & 0.075 & 6.25 & $<0.0001$ \\
Slipper-Z & -0.178 & 0.077 & -2.32 & 0.0332 \\
PC 4 & -0.130 & 0.073 & -1.78 & 0.0935 \\
\hline
\end{tabular}

\section{Indirect consumer effects}

Non-coralline (foliose) algae were more prevalent where predators were common (Fig. 2, Table 6). The effect was consistent among predators when each species was analyzed separately (Table 6). PC 3 was a significant or near significant covariate for algae in all analyses with predators, suggesting that, independent of the predator community, foliose algae were more prevalent at sites sheltered from waves and with steep slopes.

\section{Evidence for fishing effects}

Direct fishing effects

In the MANOVA, fishing was the only significant independent factor $\left(F_{5,10}=90.2, \mathrm{p}<0.0001\right)$, and a centroid plot revealed that the dependent variables were sorted from algae, hogfish, slipper lobsters, spiny lobsters, and urchins (log) along the axis of lightly fished to heavily fished.

Table 5. Algae and urchins. Response is cover of foliose algae $(\%)$. All sites $\mathrm{R}^{2}=0.61, F_{4,15}=4.7, \mathrm{p}=0.0046$. Non-significant factors (PC 2 and 4 ) removed to increase power

\begin{tabular}{|lrrrr|}
\hline Term & Estimate & \multicolumn{1}{c}{ SE } & $t$-ratio & Prob $>|t|$ \\
\hline Intercept & 47.336 & 8.354 & 5.67 & $<0.0001$ \\
log Urchin & -37.549 & 14.220 & -2.64 & 0.0185 \\
PC 1 & -6.643 & 3.321 & -2.00 & 0.0639 \\
PC 3 & 14.145 & 4.524 & 3.13 & 0.0069 \\
(log Urchin - & 30.915 & 11.430 & 2.70 & 0.0163 \\
$0.467) \times$ PC 3 & & & & \\
\hline
\end{tabular}


Table 6. Algae and predators. Sum of predators: $\mathrm{R}^{2}=0.80$, ANOVA $F_{2,17}=33.4, \mathrm{p}<0.0001$; hogfish only: $\mathrm{R}^{2}=0.72$, ANOVA $F_{2,17}=21.5, \mathrm{p}<0.0001$; slipper lobster only: $\mathrm{R}^{2}=0.54$, ANOVA $F_{2,17}=10.0, \mathrm{p}=0.0013$; spiny lobster only: $\mathrm{R}^{2}=0.48$, ANOVA $F_{2,17}=7.9, \mathrm{p}=0.0037$; all predators separately: $\mathrm{R}^{2}=$ 0.96, ANOVA $F_{9,10}=27.0, \mathrm{p}=0.000$; Non-significant factors (PC 1 and 4) removed to increase power

\begin{tabular}{|lrrrr|}
\hline Term & Estimate & SE & $t$-ratio & Prob $>|t|$ \\
\hline Sum of predators & & & & \\
Intercept & 30.700 & 3.497 & 8.78 & $<0.0001$ \\
Pred-Z & 10.946 & 1.564 & 7.00 & $<0.0001$ \\
PC 3 & 7.207 & 3.168 & 2.27 & 0.0361 \\
Hogfish only & & & & \\
Intercept & 30.7 & 4.134 & 7.43 & $<0.0001$ \\
Fish-Z & 24.220 & 4.405 & 5.50 & $<0.0001$ \\
PC 3 & 7.370 & 3.757 & 1.96 & 0.0664 \\
Slipper lobster only & & & & \\
Intercept & 30.700 & 5.265 & 5.83 & $<0.0001$ \\
Slipper-Z & 19.418 & 5.577 & 3.48 & 0.0029 \\
PC 3 & 8.819 & 4.757 & 1.85 & 0.0812 \\
Spiny lobster only & & & & \\
Intercept & 30.700 & 5.591 & 5.49 & $<0.0001$ \\
Spiny-Z & 17.117 & 5.763 & 2.97 & 0.0086 \\
PC 3 & 11.549 & 4.915 & 2.35 & 0.0311 \\
All predators together & & & & \\
Intercept & 26.520 & 3.727 & 7.12 & $<0.0001$ \\
Fish-Z & 19.509 & 3.995 & 4.88 & 0.0006 \\
Spiny-Z & -10.847 & 5.082 & -2.13 & 0.0586 \\
Slipper-Z & 31.866 & 5.213 & 6.11 & 0.0001 \\
PC 2 & -12.074 & 4.600 & -2.63 & 0.0253 \\
PC 3 & 7.959 & 2.253 & 3.53 & 0.0054 \\
Fish-Z $\times$ Slipper-Z & -18.151 & 3.486 & -5.21 & 0.0004 \\
Spiny-Z $\times$ Slipper-Z & 32.521 & 8.703 & 3.74 & 0.0039 \\
Spiny-Z $\times$ PC 2 & -21.066 & 6.006 & -3.51 & 0.0057 \\
Spiny-Z $\times$ PC 3 & 5.068 & 2.564 & 1.98 & 0.0763 \\
& & & & \\
\hline
\end{tabular}

Combined, predators were less abundant at HF sites than at LF sites (Fig. 3, Table 7). This association was stronger at sheltered and southeast sites. Similarly, when analyzed separately, hogfish $(1.7 \pm 0.33$ [SE] vs. $4.6 \pm 0.33$ ind. $\left.\mathrm{h}^{-1}\right)$, spiny lobster $(0.12 \pm 0.08$ vs. $0.39 \pm$ 0.08 ind. $\left.\mathrm{h}^{-1}\right)$, and slipper lobster $(0.07 \pm 0.025$ vs. $0.21 \pm 0.025$ ind. $\mathrm{h}^{-1}$ ) were less abundant at HF sites than at LF sites (Table 7). The association between fishing and hogfish density was greater at exposed and northwest sites (where hogfish and spiny lobster were relatively less abundant) and the difference in density for slipper lobster between HF and LF sites was greater at island sites and sites with weak currents.

\section{Indirect fishing effects}

Pencil urchin density was higher at HF sites compared to LF sites $\left(4.5 \pm 1.55\right.$ [SE] vs. $2.2 \pm 1.55$ ind. $\mathrm{m}^{-2}$, Table 8$)$. This difference was stronger at isolated islet sites with strong currents, shelter, and proximity to the northwest.

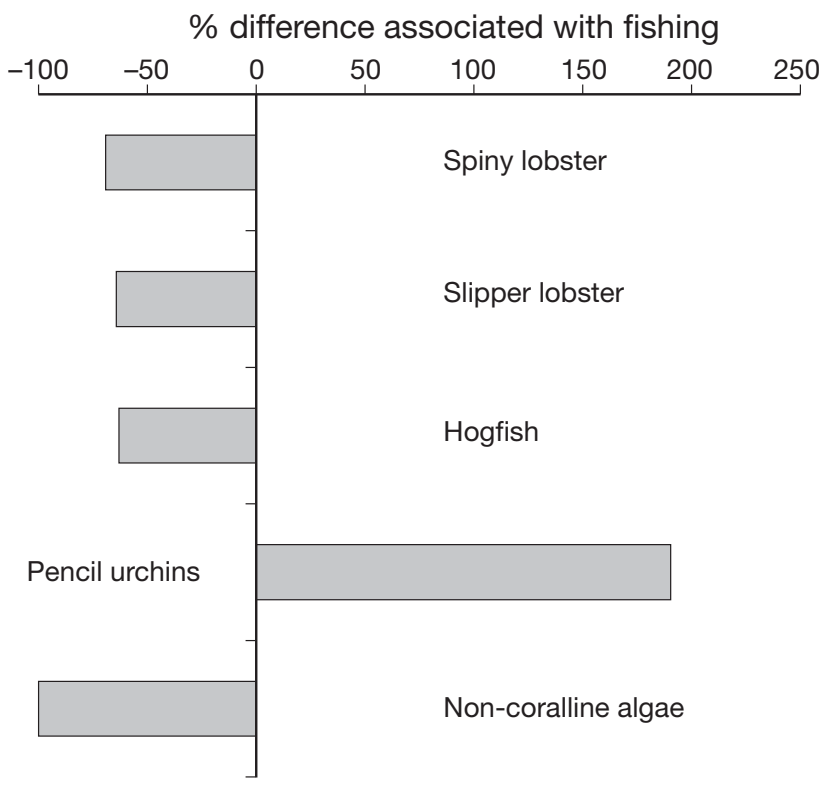

Fig. 3. Relative differences in abundance between heavily fished (HF) and lightly fished (LF) sites. The horizontal axis represents a percentage increase or decrease in untransformed mean abundance (or percent composition) for each taxon, calculated as (HF-LF)/LF

While the cover of non-coralline algae was substantially lower at HF sites, the residuals of this model were not normally distributed, nor could they be transformed. The lack of normality resulted from the presence of 2 distinct algal communities: in one, the algae were 100 to $90 \%$ non-coralline algae (algal beds/turf), while in the other the algae were 0 to $11 \%$ noncoralline algae (crustose barrens). Non-coralline algal beds dominated all LF sites. In contrast, all HF sites were barrens where $90 \%$ of the algae were encrusting coralline and articulated calcareous algae (e.g. Amphiroa spp., Corallina spp.). This difference in algal communities between HF and LF sites was highly significant (Fisher's exact test, $\mathrm{p}<0.0001$ ). Divers observed (but did not quantify) that HF sites often had high cover of the anemone Aiptasia sp., suggesting that these anemones are resistant to grazing by urchins. In some cases, anemones covered the remaining patches of the algae Ulva lactuca and Padina durvillaei.

\section{DISCUSSION}

Our results are consistent with the hypothesis of topdown control in the GMR and the related expectation that a decrease in predators associated with fishing increases herbivores and reduces algae (Fig. 2). These findings suggest the following scenario. Historically, hogfish Bodianus diplotaenia and lobsters Panulirus 
Table 7. Fishing and predators. Sum of predator Z-scores, $\mathrm{R}^{2}=$ $0.82, \mathrm{~F}_{4,15}=17.0, \mathrm{p}<0.0001$; non-significant factors (PC 1 and 2 ) removed to increase power. Hogfish Z-scores: $\mathrm{R}^{2}=0.76, F_{3,16}=$ $17.3, \mathrm{p}<0.0001$; PC 1 to 3 removed. Spiny lobster Z-scores: $\mathrm{R}^{2}=$ $0.33, F_{2,17}=4.15, \mathrm{p}=0.0341$; PC 1 to 3 removed. Slipper lobster Z-scores: $\mathrm{R}^{2}=0.74, F_{4,15}=10.5, \mathrm{p}=0.0003 ; \mathrm{PC} 3$ and 4 removed

\begin{tabular}{|lrrrr|}
\hline Term & Estimate & SE & $t$-ratio & Prob $>|t|$ \\
\hline Sum of predator z-scores & & & \\
Intercept & 2.342 & 0.400 & 5.85 & $<0.0001$ \\
Fishing & -4.500 & 0.610 & -7.38 & $<.0001$ \\
PC 3 & -0.557 & 0.265 & -2.11 & 0.0525 \\
PC 4 & -1.634 & 0.419 & -3.90 & 0.0014 \\
Fishing $\times$ PC 4 & -1.422 & 0.523 & 2.72 & 0.0158 \\
Hogfish & & & & \\
Intercept & 0.814 & 0.169 & 4.81 & 0.0002 \\
Fishing & -1.530 & 0.239 & -6.41 & $<0.0001$ \\
PC 4 & -0.760 & 0.194 & -3.92 & 0.0012 \\
Fishing $\times$ PC 4 & 0.752 & 0.243 & 3.10 & 0.0069 \\
Spiny lobster & & & & \\
Intercept & 0.448 & 0.275 & 1.63 & 0.1219 \\
Fishing & -0.896 & 0.391 & -2.29 & 0.0348 \\
PC 4 & -0.385 & 0.191 & -2.02 & 0.0597 \\
Slipper lobster & & & & \\
Intercept & 0.502 & 0.193 & 2.60 & 0.0199 \\
Fishing & -1.073 & 0.284 & -3.78 & 0.0018 \\
PC 1 & -0.165 & 0.087 & -1.89 & 0.0780 \\
PC 2 & 0.661 & 0.186 & 3.55 & 0.0029 \\
Fishing $\times$ PC 2 & -0.700 & 0.220 & -3.18 & 0.0063 \\
& & & & \\
\hline
\end{tabular}

Table 8. Fishing and urchins. Response is the log density of urchins. All sites, $\mathrm{R}^{2}=0.63, F_{4,14}=4.85, \mathrm{p}=0.0088$. PC 1 and 3 removed

\begin{tabular}{|lrcrc|}
\hline Term & Estimate & SE & $t$-ratio & Prob $>|t|$ \\
\hline Intercept & 0.346 & 0.089 & 3.88 & 0.0017 \\
Fishing & 0.309 & 0.125 & 2.47 & 0.0272 \\
PC 2 & -0.225 & 0.090 & -2.49 & 0.0261 \\
PC 4 & -0.350 & 0.104 & -3.37 & 0.0046 \\
Fishing $\times$ PC 2 & 0.248 & 0.106 & 2.33 & 0.0354 \\
Fishing $\times$ PC 4 & 0.325 & 0.129 & 2.52 & 0.0245 \\
\hline
\end{tabular}

penicillatus and particularly Scyllarides astori kept herbivore populations at low levels, and non-coralline algal communities developed because of a communitylevel trophic cascade. Where the main predators were fished, herbivores overgrazed edible algae, promoting herbivore-resistant crustose coralline algae (Harrold \& Reed 1985). Slate-pencil urchins Eucidaris galapagensis appear to play a role in this cascade. Slate-pencil urchins also graze on corals (Reaka-Kuda et al. 1996), suggesting they might have broader effects than mentioned here.

Hogfish were significantly less abundant at our HF sites. This is surprising given that this species does not formally support a commercial fishery. The apparent fishing effect might be driven by artesanal fishing for local consumption. We observed spearfishing for Bodianus diplotaenia for local sale. Several fishermen from 3 fishing cooperatives in San Cristobal, Santa Cruz and Isabela islands informally reported to us a decline in B. diplotaenia abundance in fished areas. Alternatively, hogfish might be indirectly associated with protected areas.

Our results build on a growing number of studies that indicate the importance of top-down effects in marine systems (Sala et al. 1998a). Trophic cascades can result when predators reduce the abundance of their prey to the extent that the prey's food source (plants or other prey) increases in abundance. Fishing the predators of herbivores adds a 4th level, fishers, to the top of the trophic cascade. Fishing, therefore, can affect ecosystem processes and the structure of entire communities (Sala 1997).

Like many studies on marine reserves, our study suffers from a lack of before-after comparisons, making it difficult to be certain that differences between HF and LF sites are fishing effects, not persistent site effects. For instance, reserves intentionally chosen for their high resource value might differ from fished areas independent of the effects of fishing. In addition, because it was not practical to take all measures at the same time at the same site, temporal variability could have reduced our power to detect spatial patterns. Algal communities are notably dynamic in this system. While we found significant associations between fishing and algae, other factors may contribute to spatial and temporal heterogeneity in the rocky reef community. For instance, localized upwelling will favor algal growth (consistent with our observation of more algae at cooler sites), wave energy may limit urchins to deeper areas (consistent with our observation of more urchins at sheltered sites), and heterogeneity in substrate type can alter access to shelters and habitat (Wellington 1975). Finally, our measures of urchin predation from tests were indirect and imperfect, and the mobility and cryptic nature of lobsters may have hindered accurate estimates of predator density at a particular site.

Our comparisons were spatial, but one might expect temporal patterns as well. Past studies indicate that urchin densities around the Archipelago fluctuate between 2 to 8 and 34 to 50 ind. $\mathrm{m}^{-2}$ (Glynn et al. 1979, Glynn 1990). For instance, in 1954, Eucidaris galapagensis were found to occur at a median density of 19 ind. $\mathrm{m}^{-2}$ in the western GMR (Malmquist 1991). These would be relatively high densities in our plots, and we cannot, therefore, confirm from our data the hypothesis that urchin density has increased over time as a result of increased fishing (Ruttenberg 2001, Okey 
et al. 2004). Paired comparisons of the same sites with the same methods would be needed to properly test whether urchin abundance has increased over time.

At other temperate rocky reefs, non-coralline algae provide important food and habitat for a range of species (Lilley \& Shiel 2006), suggesting that the fishing of predators can have additional indirect effects on the community. However, from our results, it is not clear whether changes in algal communities associated with fishing would have significant ecological or economic consequences. Algal abundance strongly affects the growth and mortality rates of marine iguanas (Wikelski et al. 1997). Iguanas may, therefore, compete with other herbivores for food (Shepherd \& Hawkes 2005). Understanding the value of non-coralline algae to the GMR ecosystem would provide the information necessary to weigh indirect effects of fishing against economic benefits.

The patterns seen here would not have been apparent if there were no areas where fishing was restricted, underscoring the value of protected areas, both for preserving historical conditions for future generations and for permitting a better understanding of ecological dynamics. Nonetheless, had restrictions on fishing been better enforced and implemented for a longer period of time, effects of fishing might have been easier to detect.

Future manipulative experiments could clarify the causal basis for the patterns we report. Additional replication, particularly an extension to other biogeographic regions, and studies on temporal scales that account for the effects of the El Niño Southern Oscillation, would help determine the generality of our results. Better evaluation of potentially important physical factors such as currents, wave action, and nutrients, as well as other biological factors (disease and parasitism, other predators and competitors) might help account for the considerable unexplained variance in our results. Furthermore, the GMR food web is much more complex than the elements we have studied (Okey et al. 2004). In particular, we did not collect data on other herbivores that might play a role in trophic cascades at warm sites (e.g. several sea urchins, Lytechinus semituberculatus, Diadema mexicanum, and Tripneustes depressus, can be abundant in other areas of the Galapagos). In addition, the sea urchin predators that we studied are not the only predators on sea urchins. Finally, consideration of fishing impacts on other top predators (the existing illegal fishery for sharks, and the proposed long-line fishery on pelagic fishes) and less well understood consumers (the intense fishery for sea cucumbers) would be necessary for a full evaluation of the direct and indirect effects of fishing in the Galapagos.
Acknowledgements. We gratefully acknowledge the staff and scientists of the Charles Darwin Research Station (CDRS) for their assistance and the Galapagos National Park Service (GNPS) for granting the research permits, logistic support and permission to use data. CDRS data were used for 2 of the sample-Caamaño Island (May and June, 2002) and Punta Estrada (June 2002). The GNPS provided a large boat for long trips. EcoCiencia provided an inflatable motorboat. The crew was provided by EcoCiencia and the Ecuadorian Marines, as well as by the GNPS. This study was part of a group project between EcoCiencia, the GNPS and the Ecuadorian Marines, and was funded by the World Bank with additional funding from OEA/LASPAU and AMELIS CONACYT J37689-V grants and a loan from the Inter-American Development Bank through GNPS. Mike Behrens and Nick Shears provided comments on an earlier draft. Brian Kinlan helped with the SST and CTD temperature data. Any use of trade, product, or firm names in this publication is for descriptive purposes only and does not imply endorsement by the US Government.

\section{LITERATURE CITED}

Bascompte J, Melian CJ, Sala E (2005) Interaction strength combinations and the overfishing of a marine food web. Proc Natl Acad Sci USA 102:5443-5447

Behrens MD, Lafferty KD (2004) Effects of marine reserves and urchin disease on southern California rocky reef communities. Mar Ecol Prog Ser 279:129-139

Branch GM, Witman JD, Bensted-Smith R, Bustamante RH, Wellington GM, Smith F, Edgar GJ (2002) Criterios de conservación para el bioma marino. In: Bensted-Smith $\mathrm{R}$ (ed) Visión para la biodiversidad. Fundación Charles Darwin para las Islas Galápagos y Fondo Mundial para la Naturaleza, Puerto Ayora, p 76-86

Brandt M (2003) Influencia del erizo lapicero (Eucidaris thouarsii) en la estructura de la comunidad submarina de la cara norte del Islote Caamaño, Galápagos. Tesis de licenciatura, Universidad San Francisco de Quito.

Briones EE, Sonnenholzner J, Ortiz E (2002) Caracterización de los humedales marino costeros de las Islas Galápagos: tipos de fondo costero entre profundidades de 0 y 30 metros. Fundación Ecuatoriana de Estudios Ecológicos (EcoCiencia), Banco Mundial y Servicio Parque Nacional Galápagos, Quito

Bustamante RH, Reck G, Ruttenberg B, Polovina J (2000) Spiny lobster fishing in the Galapagos Islands: historical trends and current levels of exploitation, management and conservation. In: Phillips BF, Kittaka J (eds) Spiny lobsters: fisheries and culture, 2nd edn. Fishing News Books, Oxford, p 210-220

Bustamante RH, Branch GM, Bensted-Smith R, Edgar GJ (2002) Estado y amenazas para la biodiversidad marina de Galápagos. In: Bensted-Smith R (ed) Visión para la biodiversidad. Fundación Charles Darwin para las Islas Galápagos y Fondo Mundial para la Naturaleza, Puerto Ayora, p 84-101

Bustamante RH, Okey TA, Banks S (2008) Biodiversity and food-web structure of a Galapagos shallow rocky-reef ecosystem. In: McClanahan TR, Branch GM (eds) Food webs and the dynamics of marine benthic ecosystems: a global overview. Oxford University Press, Oxford, p 135-162

Danulat E, Edgar GJ (2002) Reserva Marina de Galápagos. Línea base de la biodiversidad, Galápagos, Ecuador. Charles Darwin Foundation and the Galápagos National Park Service, Santa Cruz 
Edgar G, Fariña JM, Calvopiña M, Martínez C, Banks S (2002). Capítulo 4. Comunidades submareales rocosas II: peces y macroinvertebrados móviles. In: Danulat E, Edgar GJ (eds) Reserva Marina de Galápagos. Línea Base de la Biodiversidad. Fundación Charles Darwin/Servicio Parque Nacional Galápagos, Santa Cruz, p 68-97

Edgar GJ, Bustamante RH, Farina JM, Calvopina M, Martinez C, Toral-Granda MV (2004) Bias in evaluating the effects of marine protected areas: the importance of baseline data for the Galapagos Marine Reserve. Environ Conserv 31: 212-218

Glynn PW (1990) Coral mortality and disturbances to coral reefs in the tropical eastern Pacific. In: Glynn PW (ed) Global ecological consequences of the 1982-83 El Niño Southern Oscillation. Elsevier Oceanogr Ser 52:55-126

Glynn PW, Wellington GM, Birkeland C (1979) Coral reef growth in Galapagos: limitation by sea urchins. Science 203:47-49

Guidetti P (2006) Marine reserves reestablish lost predatory interactions and cause community changes in rocky reefs. Ecol Appl 16:963-976

Harrold C, Reed DC (1985) Food availability, sea urchin grazing, and kelp forest community structure. Ecology 66: 1160-1169

Hearn A (2004) Evaluación de las poblaciones de langostas en la Reserva Marina de Galápagos. Informe Final 20022004, Fundación Charles Darwin and Servicio Parque Nacional Galápagos, Santa Cruz

> Hearn A (2006) Life history of the slipper lobster Scyllarides astori Holthuis, 1960, in the Galapagos Islands, Ecuador. J Exp Mar Biol Ecol 328:87-97

> Hobson ES, Chess JR (2001) Influence of trophic relations on form and behavior among fishes and benthic invertebrates in some California marine communities. Environ Biol Fishes 60:411-457

> Hughes TP, Reed DC, Boyle MJ (1987) Herbivory on coral reefs: community structure following mass mortalities of sea urchins. J Exp Mar Biol Ecol 113:39-59

> Jackson JBC, Kirby MX, Berger WH, Bjorndal KA and others (2001) Historical overfishing and the recent collapse of coastal ecosystems. Science 293:629-638

Lafferty KD (2004) Fishing for lobsters indirectly increases epidemics in sea urchins. Ecol Appl 14:1566-1573

Lilley S, Shiel D (2006) Community effects following the deletion of a habitat-forming alga from rocky marine shores. Oecologia 148:672-681

Locarnini RA, Mishonov AV, Antonov JI, Boyer TP, Garcia HE (2006) Vol. 1: temperature. In: Levitus S (ed) World ocean atlas 2005. NOAA Atlas NESDIS 61, US Government Printing Office, Washington, DC, p 1-182. (CD-ROM)

Malmquist DL (1991) The past as the key to the present: taphonomy and paleoecology of the Urvina Bay Uplift. In: James MJ (ed) Galapagos marine invertebrates: taxonomy, biogeography and evolution in Darwin's islands. Plenum Press, New York, p 393-411

Martinez C (2000) Ecología trófica de Panulirus gracilis, P. penicillatus y Scyllarides astori (Decapoda, Palinura) en sitios de pesca de langosta de las Islas Galápagos. Tesis de Licenciatura, Universidad del Azuay, Cuenca (Ecuador)

Molina L, Chasiluisa C, Murillo JC, Moreno J and others (2004) Pesca blanca y pesquerías que duran todo el año, 2003. In: Evaluación de las pesquerías en la Reserva Marina de Galápagos, Informe Compendio 2003. Fundación Charles Darwin and Servicio Parque Nacional Galápagos, Santa Cruz, p 103-139

Murillo JC, Espinoza E, Edgar GJ, Nicolaides F and others
(2002) La pesca artesanal en Galápagos: comparación de indicadores entre 1997-2001. Informe Galápagos 2001/ 2002. Fundación Natura and WWF, Quito

Murillo JC, Chasiluisa C, Molina L, Moreno J and others (2003) Pesca blanca y pesquerías que duran todo el año en Galápagos, 2002. In: Evaluación de las pesquerías en la Reserva Marina de Galápagos, Informe Compendio 2002. Fundación Charles Darwin and Servicio Parque Nacional Galápagos, Santa Cruz, p 97-124

Okey TA, Banks S, Born AR, Bustamante RH and others (2004) A trophic model of a Galapagos subtidal rocky reef for evaluating fisheries and conservation strategies. Ecol Modell 172:383-401

> Pearse JS, Hines AH (1987) Long-term population dynamics of sea urchins in a central California kelp forest: rare recruitment and rapid decline. Mar Ecol Prog Ser 39: $275-283$

> Pinnegar JK, Polunin NVC, Francour P, Badalamenti F and others (2000) Trophic cascades in benthic marine ecosystems: lessons for fisheries and protected-area management. Environ Conserv 27:179-200

Reaka-Kuda ML, Feingold JS, Glynn PW (1996) Experimental studies of rapid bioerosion of coral reefs in the Galapagos Islands. Coral Reefs 15:101-107

Reck GK (1983) The coastal fisheries in the Galapagos Islands, Ecuador. Description and consequences for management in the context of marine environmental protection and regional development. $\mathrm{PhD}$ thesis, ChristianAlbrechts-Universität, Kiel

Ruttenberg BI (2001) Effects of artisanal fishing on marine communities in the Galapagos Islands. Conserv Biol 15: 1691-1699

Sala E (1997) Fish predators and scavengers of the sea urchin Paracentrotus lividus in protected areas of the north-west Mediterranean Sea. Mar Biol 129:531-539

Sala E, Boudouresque CF, Harmelin-Vivien M (1998a) Fishing, trophic cascades, and the structure of algal assemblages: evaluation of an old but untested paradigm. Oikos 82:425-439

Sala E, Ribes M, Hereu B, Zabala M, Alva V, Coma R, Garrabou J (1998b) Temporal variability in abundance of the sea urchins Paracentrotus lividus and Arbacia lixula in the northwestern Mediterranean: comparison between a marine reserve and an unprotected area. Mar Ecol Prog Ser 168:135-145

Schiel DR, Foster MS (1986) The structure of subtidal algal stands in temperate waters. Oceanogr Mar Biol Annu Rev 24:265-307

Shears NT, Babcock RC (2002) Marine reserves demonstrate top-down control of community structure on temperate reefs. Oecologia 132:131-142

Shepherd SA, Hawkes MW (2005) Algal food preferences and seasonal foraging strategy of the marine iguana, Amblyrhynchus cristatus, on Santa Cruz, Galapagos. Bull Mar Sci 77:51-72

Siversten K (2006) Overgrazing of kelp beds along the coast of Norway. J Appl Phycol 18:599-610

Snell HM, Stone PA, Snell HL (1995) Geographical characteristics of the Galápagos Islands. Not Galapagos 55:18-24

Sonnenholzner JI, Ladah LB, Lafferty KD (2007) Cascading effects of fishing on Galapagos rocky reef communities. Mar Ecol Prog Ser 343:77-85 (retracted)

Sweet WV, Morrison JM, Kamykowski D, Schaeffer BA, Banks S, McCulloch A (2007) Water mass seasonal variability in the Galapagos Archipelago. Deep-Sea Res 54: 2023-2035

Tegner MJ, Dayton PK (1981) Population structure, recruit- 
ment and mortality of two sea urchins (Strongylocentrotus franciscanus and $S$. purpuratus) in a kelp forest. Mar Ecol Prog Ser 5:255-268

Tegner MJ, Levin LA (1983) Spiny lobsters and sea urchins: analysis of a predator-prey interaction. J Exp Mar Biol Ecol 73:125-150

Editorial responsibility: Otto Kinne, Oldendorf/Luhe, Germany
Wellington GM (1975) The Galapagos coastal and marine environments. Department of National Parks and Wildlife, Quito

Wikelski M, Carrillo V, Trillmich F (1997) Energy limits to body size in a grazing reptile, the Galapagos marine iguana. Ecology 78:2204-2217

Submitted: September 24, 2007; Accepted: December 15, 2008 Proofs received from author(s): January 8, 2009 